\title{
PENGGUNAAN MODEL PEMBELAJARAN CREATIVE PROBLEM SOLVING (CPS) BERBANTUAN APLIKASI SCHEMATIC MIND MAP UNTUK MENINGKATKAN KEMAMPUAN BERPIKIR KREATIF DAN HASIL BELAJAR PESERTA DIDIK PADA MATERI STOIKIOMETRI
}

\section{Use Of Creative Problem Solving (CPS) Learning Model Aided Schematic Mind Map Application To Improve Creative Thinking Ability And Students' Learning Outcomes In Stoichiometry Materials}

Meldawati*, Rilia Iriani, Syahmani

Program Studi Pendidikan Kimia, Fakultas Keguruan dan Ilmu Pendidikan Universitas Lambung Mangkurat

Jl. Brigjen H. Hasan Basry, Banjarmasin 70123, Kalimantan Selatan, Indonesia *email: meldawati356@gmail.com

\begin{abstract}
Abstrak. Penelitian ini tentang penggunaan model pembelajaran CPS berbantuan aplikasi schematic mind map pada materi stoikiometri. Tujuan penelitian ini adalah untuk melihat: (1) perbedaan kemampuan berpikir kreatif peserta didik (2) perbedaan hasil belajar (3) peningkatan kemampuan berpikir kreatif dan hasil belajar peserta didik yang belajar menggunakan model pembelajaran CPS berbantuan aplikasi schematic mind map. Metode penelitian ini adalah quasi eksperimen dengan rancangan non-equivalent control group design. Sampel penelitian sebanyak 109 peserta didik, yaitu 36 peserta didik kelas X MIA 1, 37 peserta didik kelas X MIA 2 dan 36 peserta didik kelas X MIA 3. Sampel diambil dengan teknik purposive sampling. Analisis data menggunakan analisis deskriptif dan analisis inferensial menggunakan uji Kruskal Wallis. Penelitian memberikan hasil bahwa: (1) tampak perbedaan kemampuan berpikir kreatif penggunaan model pembelajaran CPS berbantuan aplikasi schematic mind map lebih baik dibandingkan model CPS berbantuan mind mapping dan model CPS (2) tampak perbedaan hasil belajar pengetahuan peserta didik serta rata-rata hasil belajar sikap dan keterampilan sosial penggunaan model CPS berbantuan aplikasi schematic mind map lebih baik dibandingkan model CPS berbantuan mind mapping dan model CPS (3) penggunaan model CPS berbantuan aplikasi schematic mind map dapat meningkatkan kemampuan berpikir kreatif dan hasil belajar peserta didik.
\end{abstract}

Kata kunci: CPS, aplikasi schematic mind map, berpikir kreatif, hasil belajar, stoikiometri.

\begin{abstract}
This research is about the use of CPS learning model aided schmetic mind map application in stoichiometry materials. This research aims to determine: (1) differences in students' creative thinking ability (2) differences in learning outcomes (3) Increasing creative thinking ability and student learning outcomes who learn to use the cps learning model aided schematic mind map application. The method is quasi experiment with nonequivalent control group design. The sample of this research consist of 109 students, that is 36 students of X MIA 1, 37 students of X MIA 2 and 36 students of X MIA 3. The sample is taken with purposive sampling. Data analysis using descriptive analysis and inferential analysis using Kruskal Wallis test. The research indicate results that: (1) there are differences in creative thinking ability using the CPS learning model aided schematic mind map application better than the CPS model aided mind mapping and CPS
\end{abstract}

Copyright $\odot$ JCAE-Jurnal Tugas Akhir Mahasiswa, e-ISSN 2613-9782

Program Studi Pendidikan Kimia FKIP Universitas Lambung Mangkurat 
model (2) there are differences in students' learning outcomes knowledge and the average learning outcomes of attitudes and social skills using the CPS model aided schematic mind map application better than the CPS model aided mind mapping and CPS model (3) use of CPS model aided schematic mind map application can improve creative thinking ability and students' learning outcomes.

Keywords: CPS, schematic mind map application, creative thinking, learning outcomes, stoichiometry.

\section{PENDAHULUAN}

Adanya pemberian mata pelajaran kimia di SMA satu diantaranya ditujukan untuk menumbuh kembangkan sikap kreativitas peserta didik. Kreativitas sangat perlu dikembangkan pada setiap peserta didik. Amalia, Duskri \& Ahmad (2015) menyebutkan bahwa kreativitas merupakan produk berpikir kreatif, maka agar kreativitas peserta didik dapat berkembang kemempuan peserta didik dalam berpikir kreatif juga harus dikembangkan di setiap kegiatan pembelajaran.

Kemampuan berpikir kreatif peserta didik di Indonesia umumnya termasuk kategori rendah. Kondisi ini diperlihatkan melalui Global Creativity Index yang disampaikan oleh Widiastuti \& Putri (2018) bahwa kedudukan kreativitas Indonesia berada di posisi 115 dari 139 negara. Rendahnya kemampuan berpikir kreatif peserta didik dikarenakan ketika proses pembelajaran peserta didik hanya difokuskan untuk menghafal tanpa dilatih mengasah kemampuan berpikir dan menganalisis suatu masalah, akibatnya peserta didik tidak jarang mengalami kegagalan ketika dihadapkan dengan suatu masalah yang melatih pola berpikir divergen serta peserta didik cenderung memecahkan masalah hanya dengan satu alternatif saja tanpa harus berusaha untuk mencari alternatif jawaban yang berbeda. Keadaan ini tentu mempengaruhi kemampuan berpikir kreatif peserta didik menjadi terhambat yang berdampak pada rendahnya kreativitas peserta didik.

Permasalahan utama yang sering terjadi dalam kegiatan belajar mengajar kimia di sekolah yaitu lemahnya hasil belajar peserta didik khususnya di MAN 1 HST. Hasil ujian nasional tahun ajaran 2018/2019 di MAN 1 HST hanya mencapai rata-rata mata pelajaran kimia sebesar 60,16 . Kondisi ini memperlihatkan bahwa prestasi belajar kimia peserta didik di MAN 1 HST sungguh menyedihkan. Keadaan ini nyatanya merupakan dampak dari proses belajar mengajar yang masih bersifat konvensional serta minimnya fasilitas bagi peserta didik untuk tumbuh secara mandiri melalui penemuan dalam proses berpikirnya (Al-Tabany, 2014).

Proses belajar mengajar yang diterapkan seperti demikian dapat membuat peserta didik menjadi pasif serta cenderung hanya sebagai penerima informasi saja, sehingga kemampuan berpikir kreatif dan hasil belajar peserta didik masih banyak yang buruk. Peserta didik lebih sering mengandalkan hafalan konsep yang telah dipelajarinya saja saat dihadapkan dengan suatu permasalahan namun masih kurang mampu dalam mengaplikasikan konsep tersebut untuk memcahkan masalah yang menuntut jawaban yang divergen. Hal inilah yang mengakibatkan sekolah masih belum mampu mencetak lulusan yang kreatif.

Rendahnya kemampuan berpikir kreatif dan hasil belajar peserta didik melambangkan bahwa pembelajaran masih membutuhkan perbaikan. Perbaikan proses pembelajaran dapat menjadi suatu solusi guna mengatasi rendahnya kemampuan berpikir kreatif dan hasil belajar peserta didik. Satu diantara banyaknya cara guna memperbaiki aktivitas belajar mengajar yakni dengan menentukan model pembelajaran yang pas dan sesuai. Model pembelajaran yang cocok digunakan 
untuk meningkatkan kemampuan berpikir kreatif dan hasil belajar peserta didik salah satunya adalah creative problem solving (CPS).

Model pembelajaran CPS ialah suatu model pembelajaran yang memusatkan pada keterampilan dalam memecahkan masalah yang disertai dengan penguatan keterampilan. Malisa, Bakti \& Iriani (2018) menyebutkan dengan menerapkan model CPS dapat menigkatkan kemapuan berpikir kreatif dan hasil belajar peserta didik, karena peserta didik dapat mengeksplorasi kemampuannya untuk berpikir lebih dalam, sehingga konsep yang didapatkan tidak hanya diingat tapi dipahami. Selain itu, Risnawati \& Saadi (2016) juga menyatakan pendapat yang selaras bahwa model pembelajaran CPS cocok untuk membuat peserta didik aktif dan kreatif pada proses pembelajaran. Melalui model CPS ini diharapkan mampu mendorong peserta didik untuk bisa mengatasi permasalahan yang diberikan oleh guru dengan cara yang kreatif.

Firiyah, Hariani \& Fikri (2015) dalam penelitiannya menyebutkan model CPS memiliki kekurangan satu diantaranya adalah memerlukan durasi yang relatif panjang ketika proses pembelajaran. Adanya kekurangan pada model pembelajaran CPS tersebut diperlukasn suatu solusi yaitu dengan menggunakan aplikasi schematic mina map.

Schematic mind map merupakan aplikasi pembuat mind mapping yang penggunaannya dikhususkan bagi pengguna smartphone. Schematic mind map sama seperti mind mapping pada umumnya yang dibuat secara manual menggunakan garis, kata serta warna. Hanya saja penggunaanya yang otomatis dapat dibuat jauh lebih cepat dan mudah, sehingga penggunaan aplikasi schematic mind map ini dapat menjadi metode pembelajaran yang menarik. Kurniasari \& Mardikaningsih (2018) menyebutkan dalam penelitiannya bahwa penggunaan mind mapping berbasis android merupakan bahwan ajar yang dapat meningkatkan motivasi serta prestasi belajar peserta didik.

Berdasarkan paparan di atas, maka peneliti ingin mengkaji penggunaan model pembelajaran creative problem solving (CPS) berbantuan aplikasi schematic mind map untuk meningkatkan kemampuan berpikir kreatif dan hasil belajar peserta didik pada materi stoikiometri.

\section{METODE PENELITIAN}

Bentuk rancangan penelitian kali ini yaitu eksperimen semu (quasi experimental) dengan memakai non-equivalent control group design. Penelitian ini melibatkan 3 kelas yaitu kelas eksperimen 2, kelas eksperimen 1 dan kelas kontrol. Kemampuan awal peserta didik akan diuji dengan diberi pre-test pada ketiga kelas sebelum pembelajaran berlangsung. Selanjutnya, peserta didik pada ketiga kelas akan diberi post-test guna mencari tahu pencapaian kemampuan berpikir kreatif dan hasil belajar selepas diberikan treatment di akhir pembelajaran.

Penelitian dilaksanakan di MAN 1 HST tahun pelajaran 2018/2019. Pengambilan sampel dilaksanakan secara purposive sampling. Penentuan sampel yang didasarkan atas pertimbangan dan saran dari guru mata pelajaran kimia di MAN 1 HST. Tiga kelas dari populasi dipilih sebagai sampel yaitu X MIA 2 sebagai kelas eksperimen 2 yang diberikan treatment menerapkan model pembelajaran CPS berbantuan aplikasi schematic mind map, X MIA 3 sebagai kelas eksperimen 1 yang diberikan treatment menerapkan model pembelajaran CPS berbantuan mind mapping dan X MIA 1 sebagai kelas kontrol yang diberikan treatment menerapkan model pembelajaran CPS.

Data dikumpulkan melalui dua teknik, yaitu teknik tes dan nontes. Teknik tes dilaksanakan untuk mencari tahu kemampuan berpikir kreatif serta hasil belajar 
peserta didik yang masing-masing dibuat dalam bentuk soal uraian dan pilihan ganda. Teknik nontes berupa observasi yang dilaksanakan oleh tiga orang observer guna mendapatkan data hasil belajar sikap dan keterampilan sosial peserta didik.

\section{HASIL PENELITIAN DAN PEMBAHASAN}

Hasil dari penelitian yang sudah dilaksanakan memberikan informasi tentang kemampuan berpikir kreatif dan hasil belajar (pengetahuan, sikap dan keterapilan sosial) peserta didik.

\section{Analisis Kemampuan Berpikir Kreatif}

Penelitian ini menerapkan 3 treatment yang berbeda-beda di setiap kelompok sampel selama kegiatan pembelejaran. Sebelum pembelajaran berlangsung diadakan pre-test untuk mencari tahu kemampuan awal kemudian disusul pelaksanaan posttest untuk mencari tahu dampak dari perlakuan yang diberikan yang dapat dijumpai melalui Gambar 1. Hasil uji Kruskal Wallis dapat dijumpai pada Tabel 1. Persentase rerata kemampuan berpikir kreatif di setiap indikator dapat dijumpai pada Tabel 2.

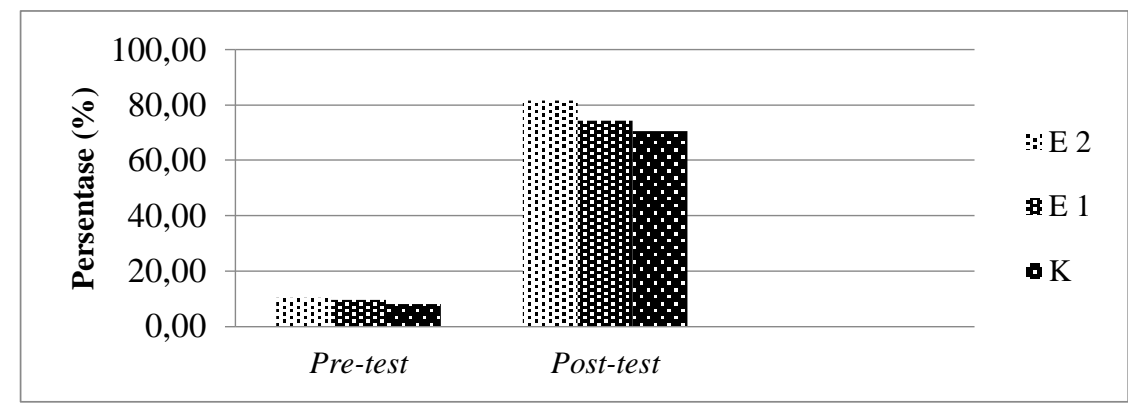

Gambar 1. Rerata nilai pre-test dan post-test kemampuan berpikir kreatif

Berdasarkan Gambar 1, kemampuan peserta didik sebelum diterapkan treatment cenderung sama. Selepas diberikan treatment dan diadakan post-test peserta didik yang melaksanakan model pembelajaran CPS berbantuan aplikasi schematic mind map memiliki nilai post-test yang lebih tinggi. Tabel 1 memperlihatkan tampak adanya perbedaan kemampuan berpikir kreatif secara signifikan antara peserta didik yang diberikan treatment model CPS berbantuan aplikasi schematic mind map, model CPS berbantuan mind mapping dan model CPS. Sehingga dapat dikatakan bahwa model pembelajaran CPS berbantuan aplikasi schematic mind map memberikan efek yang positif kepada kemampuan berpikir kreatif peserta didik. Serupa dengan penelitian Fitriyah, Hariani \& Fikri (2015) yang mengutarakan bahwa model CPS dengan mind mapping memberikan pengaruh yang signifikan dalam meningkatkan kemampuan berpikir kreatif peserta didik. Diperkuat oleh Al-Jarf (2009) yang menyatakan bahwa penggunaan software mind mapping dapat mendorong pemikiran kreatif peserta didik.

Tabel 1. Hasil uji Kruskal Wallis kemampuan berpikir kreatif

\begin{tabular}{ccccc}
\hline Hasil & Chi-square & Df & $\begin{array}{c}\boldsymbol{P} \\
\text { Asym. Sig. }\end{array}$ & Kesimpulan \\
\hline Pre-test & 3,232 & 2 & 0,199 & Tidak tampak perbedaan secara signifikan \\
Post-test & 24,268 & 2 & 0,009 & Tampakt perbedaan secara signifikan \\
\hline
\end{tabular}


Tabel 2. Persentase rerata kemampuan berpikir kreatif di setiap indikator

\begin{tabular}{cccccccc}
\hline \multirow{2}{*}{ No. } & Indikator & \multicolumn{3}{c}{ E 2 } & \multicolumn{2}{c}{ E 1 } & \multicolumn{2}{c}{ K } \\
\cline { 3 - 8 } & KBK & Pre-test & Post-test & Pre-test & Post-test & Pre-test & Post-test \\
\hline $\mathbf{1}$ & Fluency & 12,16 & 91,89 & 15,28 & 82,64 & 14,58 & 88,89 \\
$\mathbf{2}$ & Flexibility & 0,00 & 97,30 & 0,00 & 87,50 & 0,00 & 58,33 \\
$\mathbf{3}$ & Originality & 6,76 & 50,00 & 5,56 & 40,28 & 6,25 & 40,28 \\
$\mathbf{4}$ & Elaboration & 22,30 & 86,49 & 16,67 & 86,11 & 11,11 & 94,44 \\
\hline
\end{tabular}

Indikator fluency. Kelas eksperimen 2 mempunyai kemampuan berpikir kreatif pada indikator fluency yang lebih unggul dibandingkan kelas eksperimen 1 maupun kelas kontrol. Pengetahuan peserta didik di kelas eksperimen 2 sudah terlebih dulu terbentuk pada pembuatan mind mapping melalui aplikasi schematic mind map sehingga peserta didik lebih siap menerapkan pengetahuan yang sudah dimiliki sebelumnya untuk menghadapi masalah. Sesuai dengan pendapat Savitri, Saadi \& Leny (2019) pada tahapan fluency peserta didik menampung banyak informasi yang sudah mereka miliki sebelumnya untuk memecahkan masalah dengan memikirkan lebih dari satu kemungkinan jawaban.

Indikator flexibility. Kelas eksperimen 2 mengalami peningkatan terbaik bagi indikator flexibility. Kondisi ini mengindikasikan bahwa kelas eksperimen 2 lebih sanggup memberikan lebih dari satu alternatif penyelesaian masalah dibandingkan kelas eksperimen 1 maupun kelas kontrol. Dalam tahapan idea finding dan solution finding pada model CPS peserta didik diberikan kebebasan guna menuangkan ide atau solusi pemecahan masalah dari berbagai sumber. Ketika pembelajaran berlangsung peserta didik kelas eksperimen 2 pada semua kelompok mampu memberikan lebih dari satu alternatif pemecahan masalah sehingga ketika dihadapkan dengan suatu permasalahan, sehingga peserta didik lebih mampu untuk memberikan lebih dari satu solusi pemecahan masalah. Fitri \& Septiana (2013) menyebutkan bahwa tingginya kemampuan flexibility peserta didik satu diantaranya ditandai dengan kemampuan peserta didik dalam merencanakan berbagai macam solusi guna menghadapi suatu masalah.

Indikator originality. Kelas eksperimen 2 memegang pencapain yang lebih dominan dibandingkan kelas eksperimen 1 maupun kelas kontrol. Keadaan ini memperlihatkan bahwa peserta didik kelas eksperimen 2 lebih mampu dalam memberikan solusi jawaban yang unik dan orisinil. Secara keseluruhan pada indikator originality pencapaian peserta didik masih tergolong rendah. Kurangnya penekanan peneliti pada tahapan idea finding dan solution finding merupakan salah satu penyebab sedikitnya pencapaian peserta didik pada indikator originality.

Indikator elaboration. Kelas kontrol memperoleh pencapaian yang lebih tinggi pada indikator elaboration. Ketika diadakan post-test peserta didik kelas kontrol lebih banyak menjawab soal pada indikator elaboration terlebih dahulu sehingga kemampuan mereka saat memperinci jawaban di kelas kontrol lebih unggul dibandingkan kelas eksperimen 2 maupun kelas eksperimen 1 yang belakangan menjawab soal indikator elaboration walaupun jawabannya benar.

Secara keseluruhan peserta didik sudah mengalami peningkatan kemampuan berpikir kreatif di setiap indikator. Hal ini memperlihatkan bahwa dengan diberikannya model CPS pada ketiga kelas tersebut mampu meningkatkan kemampuan berpikir kreatif peserta didik. Adanya pembuatan mind mapping menggunakan aplikasi schematic mind map juga ikut berperan dalam meningktkan kemampuan berpikir kreatif pesrta didik. Selaras dengan pendapat Wati, Leny \& Saadi (2017) bahwa model pembelajaran CPS berbantuan multimedia interaktif dapat meningkatkan kemapuan berpikir kreatif peserta didik yang terjadi pada 
semua indikator. Peningkatan kemampuan berpikir kreati peserta didik dapat dilihat melalui hasil uji Wilcoxon dalam Tabel 3.

Tabel 3. Hasil uji Wilcoxon kemampuan berpikir kreatif

\begin{tabular}{|c|c|c|c|c|c|c|c|c|}
\hline Kelas & $\mathbf{N}$ & Data & Mean & $\begin{array}{c}\text { Selisi } \\
\mathbf{h}\end{array}$ & $Z$ & $\begin{array}{c}P \\
\text { Asym } \\
\text {. Sig. }\end{array}$ & $\begin{array}{c}p \\
\text { (Sig.) } \\
(1- \\
\text { tailed) }\end{array}$ & Kesimpulan \\
\hline E 2 & 37 & $\begin{array}{l}\text { Pre-test } \\
\text { Post-test }\end{array}$ & $\begin{array}{l}10,39 \\
81,42\end{array}$ & 71,12 & $-5,349$ & 0,000 & 0,000 & $\begin{array}{c}\mathrm{H}_{0} \text { ditolak } \\
\mathrm{H}_{1} \text { diterima }\end{array}$ \\
\hline E 1 & 36 & $\begin{array}{l}\text { Pre-test } \\
\text { Post-test }\end{array}$ & $\begin{array}{c}9,38 \\
74,13\end{array}$ & 64,75 & $-5,255$ & 0,000 & 0,000 & $\begin{array}{c}\mathrm{H}_{0} \text { ditolak } \\
\mathrm{H}_{1} \text { diterima }\end{array}$ \\
\hline K & 36 & $\begin{array}{l}\text { Pre-test } \\
\text { Post-test }\end{array}$ & $\begin{array}{r}7,99 \\
70,49 \\
\end{array}$ & 62,50 & $-5,257$ & 0,000 & 0,000 & $\begin{array}{c}\mathrm{H}_{0} \text { ditolak } \\
\mathrm{H}_{1} \text { diterima }\end{array}$ \\
\hline
\end{tabular}

Hasil uji Wilcoxon memberitahukan tampak ada perbedaan nilai pre-test dan post-test kemampuan berpikir kreatif di ketiga kelas yang dibuktikan dengan ditolaknya $\mathrm{H}_{0}$ dan $\mathrm{H}_{1}$ diterima dengan nilai post-test lebih meningkat setelah diberikan perlakuan.

\section{Analisis Hasil Belajar}

Hasil uji Kruskal Wallis, persentase ketuntasan peserta didik serta hasil uji Wilcoxon hasil belajar pengetahuan dapat dijumpai pada Tabel 4, Tabel 5 dan Tabel 6.

Tabel 4. Hasil uji Kruskal Wallis hasil belajar pengetahuan

\begin{tabular}{|c|c|c|c|c|c|}
\hline Hasil & Chi-square & $D f$ & $\begin{array}{c}p \\
\text { Asym. Sig. }\end{array}$ & \multicolumn{2}{|c|}{ Kesimpulan } \\
\hline Pre-test & 0,855 & 2 & 0,652 & \multirow{2}{*}{\multicolumn{2}{|c|}{$\begin{array}{c}\text { Tidak tampak perbedaan secara signifikan } \\
\text { Tampak perbedaan secara signifikan }\end{array}$}} \\
\hline Post-test & 14,828 & 2 & 0,001 & & \\
\hline \multicolumn{2}{|c|}{ Nilai } & \multicolumn{2}{|c|}{ Kelas Eksperimen 2} & Kelas Eksperimen 1 & Kelas Kontrol \\
\hline \multicolumn{2}{|c|}{$\geq 75$ (Tuntas) } & \multicolumn{2}{|r|}{33} & 29 & 19 \\
\hline \multicolumn{2}{|c|}{$<7 \overline{5}$ (Tidak tuntas) } & \multicolumn{2}{|r|}{4} & 7 & 17 \\
\hline \multicolumn{2}{|c|}{$\begin{array}{c}\text { Ketuntasan kelas } \\
(\%)\end{array}$} & \multicolumn{2}{|r|}{89,19} & 80,55 & 52,78 \\
\hline
\end{tabular}

Tabel 6. Hasil uji Wilcoxon hasil belajar pengetahuan

\begin{tabular}{|c|c|c|c|c|c|c|c|c|}
\hline Kelas & $\mathbf{N}$ & Data & Mean & $\begin{array}{c}\text { Selisi } \\
\mathbf{h}\end{array}$ & $Z$ & $\begin{array}{c}p \\
\text { Asym } \\
\text {. Sig. }\end{array}$ & $\begin{array}{c}p \\
\text { (Sig.) } \\
(1- \\
\text { tailed) }\end{array}$ & Kesimpulan \\
\hline E 2 & 37 & $\begin{array}{l}\text { Pre-test } \\
\text { Post-test }\end{array}$ & $\begin{array}{l}37,30 \\
88,65\end{array}$ & 51,35 & $-5,333$ & 0,000 & 0,000 & $\begin{array}{c}\mathrm{H}_{0} \text { ditolak } \\
\mathrm{H}_{1} \text { diterima }\end{array}$ \\
\hline E 1 & 36 & $\begin{array}{l}\text { Pre-test } \\
\text { Post-test }\end{array}$ & $\begin{array}{l}36,67 \\
82,78\end{array}$ & 46,11 & $-5,277$ & 0,000 & 0,000 & $\begin{array}{c}\mathrm{H}_{0} \text { ditolak } \\
\mathrm{H}_{1} \text { diterima }\end{array}$ \\
\hline K & 36 & $\begin{array}{l}\text { Pre-test } \\
\text { Post-test }\end{array}$ & $\begin{array}{l}37,78 \\
78,61\end{array}$ & 40,83 & $-5,269$ & 0,000 & 0,000 & $\begin{array}{c}\mathrm{H}_{0} \text { ditolak } \\
\mathrm{H}_{1} \text { diterima }\end{array}$ \\
\hline
\end{tabular}

Tabel 5 dan Tabel 6 menunjukkan jika kelas eksperimen 2 lebih banyak mencapai ketuntasan dibandingkan kelas eksperimen 1 maupun kelas kontrol. Peristiwa ini memperlihatkan jika kelas eksperimen 2 yang menerapkan model pembelajaran CPS berbantuan aplikasi schematic mind map lebih berperan dalam 
meningkatkan hasil belajar pengetahuan. Pada Tabel 4 juga disebutkan tampak ada perbedaan secara signifikan pada hasil post-test peserta didik. Perbedaan ini tidak terlepas dari adanya penerapan model pembelajaran CPS berbantuan aplikasi schematic mind map. Irliyani, Kusasi \& Hamid (2018) menyebutkan adanya tambahan mind mapping dalam pembelajaran dapat mendukung peserta didi lebih gampang dalam mencerna dan mengingat informasi sehingga berpengaruh signifikan kepada hasil belajar pengetahuan peserta didik.

Selanjutnya, hasil beljar sikap peserta didik yang terdiri dari aspek rasa ingin tahu serta tanggung jawab. Data diperoleh melalui observasi yang dilakukan observer ketika pembelajaran berlangsung. Berikut persentase rerata sikap peserta didik dapat dijumpai pada Gambar 2.

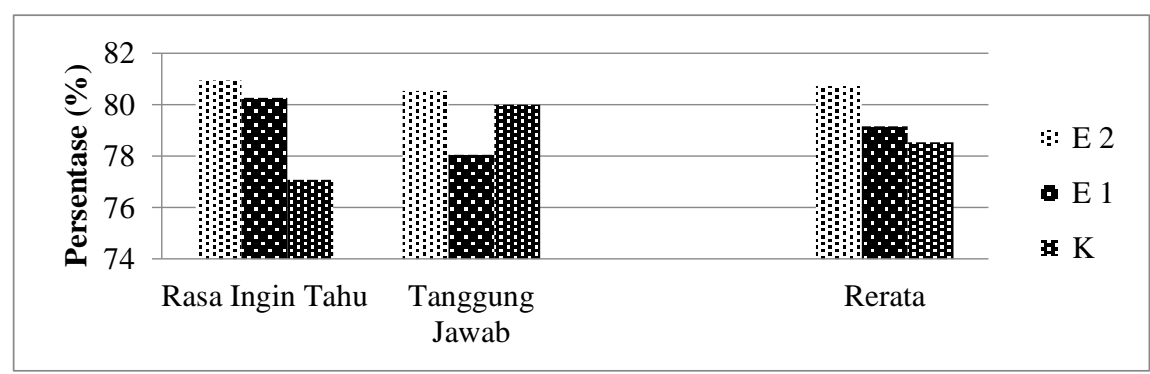

Gambar 2. Persentase rerata sikap peserta didik

Gambar 2 mengindikasikan bahwa pembelajaran yang menerapkan model pembelajaran CPS berbantuan aplikasi schematic mind map menghasilkan dampak yang positif pada hasil belajar sikap peserta didik baik pada aspek rasa ingin tahu maupun tanggung jawab. Keadaan ini menunjukkan bahwa pada setiap langkah dalam model pembelajaran CPS dapat memicu rasa ingin tahu peserta didik. Peserta didik tidak sungkan untuk menanyakan hal-hal yang kurang dipahaminya baik pada guru atau teman sejawatnya mengenai hal-hal yang dapat membantunya dalam menyelesaikan masalah melalui penerapan model CPS. Selain itu adanya pembuatan mind mapping melalui aplikasi schematic mind map sebelum pembelajaran berlangsung juga dapat menumbuhkan rasa ingin tahu dan tanggung jawab menjadi lebih baik. Keles \& Ozgul (2012) mengatakan bahwa dengan penggunaan mind mapping, aktivitas peserta didik dan kerjasama pendekatan pembelajaran pada rasa keingin tahuan dan integrasi pengetahuan subjek yang berbeda-beda menjadi berkembang.

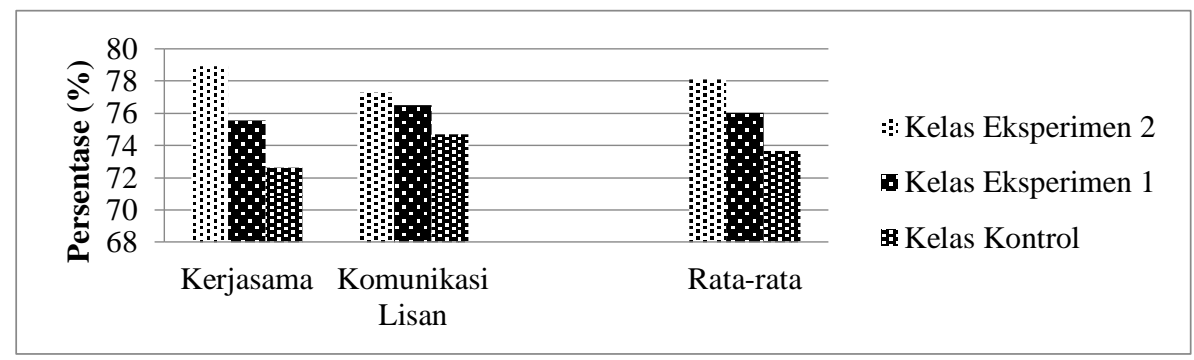

Gambar 3. Persentase rata-rata keterampilan sosial peserta didik 
Gambar 3 menunjukkan hasil belajar keterampilan sosial peserta didik ketiga kelas sama-sama dalam kategori baik untuk kedua aspek yaitu kerjasama dan komunikasi lisan. Kelas eksperimen 2 memilki rata-rata nilai keterampilan sosial yang lebih unggul dibandingkan kelas eksperimen 1 maupun kelas kontrol. keadaan ini mengindikasikan jika penerapan model CPS berbantuan aplikasi schematic mind map mampu memberikan dampak yang positif terhadap keterampilan sosial peserta didik di kelas eksperimen 2. Hasil penelitian Risna, Hamid \& Winarti (2017) menyatakan dengan diterapkannya model CPS dapat memicu peserta didik berpikir aktif dan meningktkan kerjasama ketika menyelesaikan suatu masalah.

\section{SIMPULAN}

Hasil penelitian dan pembahasan dapat ditarik kesimpulan bahwa adanya kemampuan berpikir kreatif peserta didik yang berbeda secara signifikan antara peserta didik yang diberlakukan treatment model CPS berbantuan aplikasi schematic mind map, model CPS berbntuan mind mapping serta model pembelajaran CPS. Hasil belajar pengetahuan peserta didik juga ada perbedaan signifikan antara peserta didik yang diberlakukan treatment model CPS berbantuan aplikasi schematic mind map, model CPS berbantuan mind mapping dan model pembelajaran CPS serta rerata hasil belajar sikap dan keterampilan sosial peserta didik yang diberikan treatment model CPS berbantuan aplikasi schematic mind map lebih unggul dibandingkan treatment model CPS berbantuan mind mapping maupun model CPS. Penggunaan model pembelajran CPS berbantuan aplikasi schematic mind map dapat meningkatkan kemampuan berpikir kreatif peserta didik dari rata-rata nilai kemampuan berpikir kreatif sebesar 10,30 ketika pre-test menjadi 81,42 ketika post-test, serta dapat meningkatkan hasil belajar pengetahuan peserta didik dari rata-rata nilai sebesar 37,30 ketika pre-test menjadi 88,65 ketika post-test.

\section{DAFTAR RUJUKAN}

Al-Tabany, T. I. (2014). Mendesain Model Pembelajaran Inovatif, Progresif dan Kontekstual. Jakarta: Kencana.

Amalia, Y., Duskri, M., \& Ahmad, A. (2015). Penerapan Model Eliciting Activities untuk Meningkatkan Kemampuan Berpikir Kreatif Matematis dan Self Confidence Siswa SMA. Jurnal Didaktik Matematika, 2(2), 296-313.

Fitri, S. G., \& Septifiana, V. (2013). Kreativitas Siswa dalam Pembuatan Model truktur 3D Sel pada Pembelajaran Subkonsep Struktur dan Fungsi Sel. Prosiding Semirata FMIPA Universitas Lampung, 2(2), 333-338.

Fitriyah, N., Hariani, A. S., \& Fikri, K. (2015). Pengaruh Model Pembelajaran Creative Problem Solving (CPS) dengan Mind Mapping terhadap Kemampuan Berpikir Kreatif dan Hasil Belajar IPA Biologi. Jurnal Edukasi, 2(2), 44-50.

Irliyani, F., Kusasi, M., \& Hamid, A. (2018). Implementasi Model Discovery Based Learning Berbantuan Mind Mapping Terhadap Sikap Ilmiah dan Hasil Belajar Peserta Didik Pada Materi Koloid. JCAE Journal of Chemistry and Education, 2(1), 17-24.

Keles, \& Ozgul. (2012). Mind maps and scoring scale for environmental gains in science education. Journal of Baltic Science Education, 4(3), 34-43.

Kurniasari, P., \& Mardikaningsih, A. (2018). Pengembangan Aplikasi e-MindMaps pada Materi Ilmu Sosial dan Budaya Dasar Memanfaatkan Groupware Berbasis Android. Jurnal Penelitian Pendidikan, 35(2), 179-186. 
Malisa, S., Baikti, I., \& Iriani, R. (2018). Model Pembelajaran Creative Problem Solving (CPS) Untuk Meningkatkan Hasil Belajar dan Kemampuan Berpikir Kreatif Siswa. Jurnal Vidya Karya, 33(1), 1-20.

Risna, Hamid, A., \& Winarti, A. (2017). Meningkatkan Keterampilan Generik Sains dan Hasil Belajar Menggunakan Model Creative Problem Solving Dilengkapi Laboratorium Virtual Materi Hidrolisis Garam Kelas I IPA 2 SMA PGRI 4. JCAE Journal of Chemistry and Education, 1(1), 131-142.

Risnawati, \& Saadi, P. (2017). Meningkatkan Kemampuan Berpikir Kreatif dan Hasil Belajar Melalui Model Pembelajaran Creative Problem Solving (CPS) pada Materi Larutan Penyangga. Quantum Jurnal Inovasi Pendidikan Sains, 7(1), 131-142.

Savitri, E., Saadi, P., \& Leny. (2019). Model Pembelajaran CORE Berbentuan Mind Mapping dalam Meningkatkan Kemampuan berpikir kreatif Peserta Didik pada Materi Stoikiometri. Quantum Jurnal Inovasi Pendidikan Sains, 10(1), 68-75.

Wati, N. N., Leny, \& Saadi, P. (2017). Meningkatkan Kemampuan Berpikir Kreatif dan Hasil Belajar Melalui Model Pembelajaran Creative Problem Solving Berbantuan Multimedia Interaktif pada Materi Larutan Penyangga di SMAN 4 Banjarmasin. JCAE Journal of Chemistry and Education, 1(1), 104-110.

Widiastuti, Y., \& Putri, R. I. (2018). Kemampuan Berpikir Kreatif Siswa pada Pembelajaran Operasi Pecahan Menggunakan Pendekatan Open-Ended. jurnal pendidikan matematika, 2(2), 13-22. 